\title{
Sağlık Yönetmi Stajyer Öğrencilerinin Yeterliliklerinin Değerlendirilmesi: Bir Alan Araştırması
}

\section{Determining the Level of Proficiency of Healthcare Management Students: A Field Study}

\author{
Selma SÖYÜK ${ }^{a}$ İbrahim GÜN ${ }^{b}$
}

ÖZET Amaç: Bu çalışmanın amacı, sağlık yönetimi bölümünü lisans öğrencilerinin staja çıktıkları kurumlardaki birim yöneticileri tarafindan yapılan değerlendirme sonucunda yeterliliklerinin ne düzeyde olduklarını ortaya koymaktır. Çalışma birim yöneticileri bazında yapılmıştır.Gereç ve Yöntem: Araştırmada veri toplama aracı olarak anket formu kullanılmıştır. Anket iki bölümden oluşmaktadır. İlk bölümde anketi cevaplayan birim yöneticilerine ait demografik bilgiler yer alırken, ikinci bölümde yöneticilerin stajyer öğrenciler hakkındaki görüşlerini belirten ölçeğe yer verilmiştir. Araştırma, gerekli izinler alındıktan sonra Ekim-Şubat 2016 tarihleri arasında İstanbul'da sağlık yönetimi öğrencilerinin staja çıkmış oldukları hastaneler arasından çalışmaya katılmayı kabul eden 11 hastanede uygulanmıştır. Veriler SPSS 20.0 Programı ile analiz edilmiştir. Bulgular: Araştırmaya 11 farklı hastaneden (32Kamu; 19- Özel) 51 birim yöneticisi katılmıştır. Çalışmaya katılanların demografik özelliklerine baktığımızda; katılanların 26 (\%51)'sı kadın, 25 (\%49)'i erkektir. Ankete katılanların çoğu 32-40 yaş aralığındadır. Stajyer seçimine dikkat edilmesi gereken kriterlere baktığımızda \%20,48 ile eğitim olduğu saptanmıştır. Staj dönemi en çok yaşanan sorunların başında \%20,98 ile mesai saatleri olmuştur. İşine özen göstermemeleri gelen cevapların \%11,11'ini oluştururken; öğrencilerin bilgi yetersizliği olduğu cevapların \%9,87'sinde belirtilmiştir. Stajyer öğrenciler hakkındaki

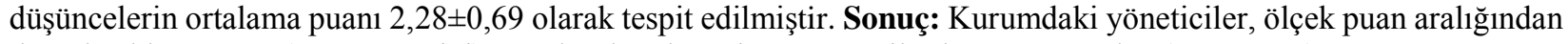

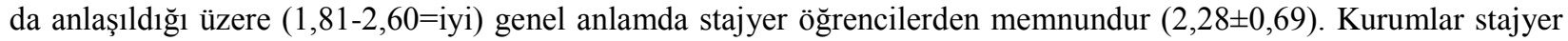
öğrenci alımlarında en çok eğitim düzeyine önem verirken, stajyer öğrencilerle en çok mesai kavramına uyum konusunda sorun yaşamaktadırlar. Çalışama sonucunda öğrencilerin teoride aldıkları bilgilerin uygulama aşamasında iş gerekliliklerine göre kullanılmasının öğrenciler hakkındaki genel memnuniyet düzeyi üzerinde etkili olduğu düşünülmektedir.

Anahtar Kelimeler: Sağlık yönetimi, sağlık yönetimi stajı, staj sorunları, stajların değerlendirilmesi

\begin{abstract}
Purpose: The aim of this study is to determine level of competence of students who studying healthcare management by functional managers of health instutitions where they are undergoing training. The study is conducted on the basis of functional managers. Methods: Questionnaire form which consists of two parts is being used in this study. In the first section, demographic questions has been asked to the functional managers and in the second part a scale which measures proficiency of students. After we got permissions from instutitions that are voluntary to attend this research in İstanbul, the study has been conducted in 11 hospitals between October 2015 and Februrary 2016. Collected data has been analyzed by using SPSS 20.00. Results: 51 functional manager has joined this reseach from 11 different hospitals (32 public, 19 private). When we analyze demographic characteristics of participants, it has been understood that 26 (51\%) people are women whereas 25 of them (49\%) are consist from man. Majority of participants age changes between 32-40. In choosing process of trainer, managers indicate that, they were paying attention 20,48\% education level which is the most important criteria for them. Problems that managers are facing during the internship with students consist of adaptation of working hours (20,98\%), not care two hoots (11.11\%), lack of information $(9,87 \%)$. Mean score of students has been determined 2,28 $\pm 0,69$. Conclusion: Functional manager are generally pleased with the proficiency of student $(2,28 \pm 0,69)$. According to them the most important criteria while they are choosing trainers is education level of students. The biggest problem that they are facing is adaptation of working
\end{abstract}

Geliş Tarihi/Received: 14-12-2016/ Kabul Tarihi/Accepted:09-05-2017

${ }^{a}$ Yrd. Doç. Dr. İstanbul Üniversitesi Sağlık Bilimleri Fakültesi, E-posta: selmasoyuk@hotmail.com

b Arş. Gör. İstanbul Üniversitesi Sağlık Bilimleri Fakültesi, E-posta: ibrahimgun1@gmail.com

Sorumlu yazar /Correspondence: Arş. Gör. İbrahim GÜN, İstanbul Üniversitesi Sağlık Bilimleri Fakültesi, Eposta: ibrahimgun1@gmail.com 
hours. Theoretical information that students using during their internship is adding additional value to their internship process and enhance the satisfaction level of managers.

Key Words: Healhcare management, healhcare management internship, internship issues, evaluation of internship

\section{Giriş}

Sağlık, bir hastalık ya da sakatlığın olmayışı değil aynı zamanda bedenen ruhen ve sosyal yönden tam bir iyilik halidir. ${ }^{1}$ Dünya Sağlik Örgütü'nün yapmış olduğu sağlık tanımlaması gereğince sağlı̆̆ın yönetilmesinin sadece belirli meslek grupları tarafindan değil, multidisipliner olarak yapılması gerektiği anlaşılmaktadır. Örgütsel amaçların örgütsel kaynaklarla başarılmasını sağlayan yönetim kavramı, post modern çağımızda el ucuyla yapılan bir iş olmaktan ziyade profesyoneller tarafindan yürütülmesi gereken bir süreçtir.

Hastanelerde talebin ve maliyetinin artması, verimliliğin ve etkinliğin artırılmasını zorunlu hale getirmiştir. Verimliliğin ve etkinliğin artırılmasında en önemli etmenlerinden biri de yönetim alanında uzman sağlı profesyoneli yetiştiren programlardır. ${ }^{2} \quad$ Yükseköğretim kurumlarında, yönetici yetiştirme rolünü üstlenen eğitim programları ülkenin nitelikli yönetici ihtiyacına cevap vermeyi amaçlamaktadır. Sağlık yönetimi lisans ve lisansüstü programları da ülkenin sağlık alanındaki yönetici ihtiyacına cevap verebilmek adına faaliyetlerini sürdüren önemli eğitim programlarıdır.

Sağlık statüsü göstergelerinde son yıllarda meydana gelen iyileşmelerle beraber (bebek ölüm hızının azalması, anne ölüm hızının azalması, ortalama yaşam yılının yükselmesi vb.), ülkelerin sağl1k statüsü göstergelerini daha da ileriye götürmeleri her geçen y1l daha da zor bir hal almaktadır. ${ }^{3} \mathrm{Bu}$ da sağlığın yönetimi konusunda uzmanlaşmanın, çalışmaları daha da ileriye götürecek yetişmiş insan kaynağının gerekliliğini ortaya koymaktadir.

Günümüzde teknoloji alanında meydana gelen baş döndürücü hızdaki değişim ve gelişim, teknolojiye duyarlı, iletişim becerisi yüksek, yardımsever, kişisel gelişime önem veren ve durumsallık yaklaşımı çerçevesinde meydana gelen olayları analiz etme becerisine sahip nitelikli sağlık personeli ve yönetici ihtiyacını zorunlu kılmıştır. Sağlık yönetimi lisans programları da gereken nitelikli personel ve yönetici ihtiyacını karşılamak adına verdikleri teorik eğitimlere destek olarak staj uygulamasinı zorunlu olarak öğrencilerine sunmaktadır.

Eğitimin temel amacı öğrencilere bilgi transferini başarılı bir şekilde gerçekleştirmektir. Eğitimin bu amacı doğrultusunda staj uygulamalarına da yer verilmektedir. ${ }^{4}$ Staj, kuramsal meslek bilgisine sahip kişilerin, alanlarında aldıkları akademik bilgileri gerçek yaşamda kullanma ve deneme, diğer bir deyişle, edindiği bilgileri yaparak ve yaşayarak davranışa dönüştürme deneyimi biçiminde ifade edilmektedir. ${ }^{5}$ Staj uygulamasının sağladığı bir diğer yarar da Bos ve arkadaşları tarafindan "Stajlar bilgiyi farklı konularda ilerletmeyi sağlar ve bize çeşitli ortamlarda çalışmaya uyum sağlama deneyimini sağlar." şeklinde ifade edilmiştir. ${ }^{6}$

Staj süreci, sağlık yönetimi öğrencilerin eğitim dönemleri içerisinde, iş dünyası ile tanışma aşaması olarak görülmekte ve öğrencilerin kazandıkları bilgileri uygulamaya geçirmelerinin ancak sağlık işletmelerinde staj yapmalarıyla mümkün olabileceği belirtilmektedir. ${ }^{7}$

Öğrencilerin staj uygulamalarından edindikleri faydalar birçok araştırmacı tarafından vurgulanmaktadır ${ }^{8}$ Örneğin Coco bu faydaları şu şekilde sıralamaktadır. ${ }^{9}$

- Sınıf içi ve uygulamaları ilişkilendirme yeteneği

- Kariyer planlamasında bilgi gelişimi

- Kariyer tutkularını ve ilgi alanlarını netleştirme

- Alana girdiğinde yaşanılabilecek şoku azaltma

- Hızlı gelişim.

Sağl1k Bilimleri Fakültesi Sağlık Yönetimi Bölümü dördüncü sinıf öğrencileri tarafindan yapılan staj programı genel olarak, sağlık işletmelerinin organizasyon yapılarını, idari, mali ve teknik fonksiyonlarının işleyişinin uygulama eğitimini amaçlamaktadır. ${ }^{10}$

Öğrencilerin eğitim kurumlarında edindikleri teorik bilgi ve iş yöntemlerini, çalışma yaşamında uygulamaya dökebilmeleri oldukça önemlidir. Bir yandan teorik bilgi ve pratik becerilerin bütünleşmesi, diğer yandan da 
uzmanlaşabilmek için mesleki deneyim kazanmaları açısından staj dönemi, kariyerin önemli bir parçası olarak değerlendirilmektedir. ${ }^{11}$

Hastanelerin de, toplumun gereksindiği sağlık hizmetlerini karşılamak amacıyla faaliyet gösteren emek-yoğun teknolojiye sahip bir örgüt olduğu göz önüne alındığında belirlenen amaca ulaşmada, hastanenin başarısı ve başarısızlığ personeline bağlıdır. Hastanede görevli birçok meslek grubu vardır. $\mathrm{Bu}$ meslek gruplarının hastane amaçları doğrultusunda faaliyet gösterebilmeleri için doğru yönetim ilkeleriyle bir araya getirilmiş olması ve koordine edilmesi gerekmektedir. $^{12}$

Türkiye'de sağlı hizmetleri alanında yönetici gereksiniminin karşılanmasına yönelik olarak ilk yükseköğretim kurumu 1963 yılında Sağlık Sosyal Yardım Bakanlığı (SSYB) tarafından kurulan "Sağlık İdaresi Yüksek Okulu" dur. ${ }^{13} 2016$ ÖSYS Kontenjan Kılavuzu'na göre sağlık yönetimi alanında Türkiye'de lisans düzeyinde eğitimi veren 51 üniversite bulunmaktadır. ${ }^{14}$

Jamison ve Clayton 2016 yılında yapmış oldukları çalışmada, yönetsel anlamda da staj uygulamalariyla beraber stajyerlerin deneyimlerinin geliştiğini vurgulamışlardır. Stajyerlerinin bu tecrübelerin, gelişim endişeleri çerçevesinde nasıl bir anlam ifade ettiklerinin etkilerini ifade etmiş, yönetici hazırlığı alanındaki araştırmalara katkıda bulunarak katma değer yarattıklarını ifade etmişlerdir. ${ }^{15}$

Staj gerek bireysel, gerek profesyonel iş hayatında önemli değişiklikler ve gelişmelere olanak sağlayan uygulama eğitimi olarak karşımıza çıkmaktadır. İş hayatında karşıllaşılabilecek birçok olay staj uygulaması sırasınca öğrenciler tarafından gözlemlenmekte ve gelişim süresince katma değer yaratmaktadır. ${ }^{16} \mathrm{Bu}$ çalışma, staja çıkan sağlık yönetimi öğrencilerinin, staj yaptıkları kurumlarda onları yakından tanıma firsat1 bulan birim yöneticileri tarafindan değerlendirilmesi amacıyla gerçekleştirilmiştir Çalışmanın bir diğer amacı da, stajlarda olan sorunları belirleyerek kurum ve öğrenciler açısından daha sonraki stajların daha verimli geçmesini sağlamaktır.

\section{Gereç ve Yöntemler}

Tanımlayıcı türde planlanan bu araştırma, İstanbul'da sağl1k yönetimi bölümü öğrencilerinin staj yaptıkları kurumlardaki birim yöneticileriyle yüz yüze anket yöntemi ile gerçekleştirilmiştir. Gerekli izinler alındıktan sonra Ekim-Şubat 2015 ayları arasında birim yöneticilerinden randevular alınarak anket formları elden teslim edilmiş ve anket açıklamaları yapılmıştır. Yöneticilerin anketleri yanitlanmasi beklenerek geri toplanmıştır. Araştırmada kullanılan veri toplama aracı 3 bölümden oluşmaktadır. İlk bölümde araştırmaya katılan yöneticinin demografik bilgilerini değerlendirdiğimiz sorular, ikinci bölümde Dayığlu tarafından oluşturulan, staj öğrencilerinin yeterliliğini yöneticiler gözünden ölçen, sorulara yer verilmiştir. ${ }^{17}$ Ölçeğe göre belirli aralıklarda değerlendirmeler yapılmıştır. Ortalama sonucu 1,00-1,80 çok iyi, 1,81-2,60 iyi, 2,61-3,40 orta, 3,41-4,20 az, 4,21-5,00 çok az şeklinde değerlendirilmiştir. Son bölümde de sağlık yönetimi alanında uzman kişilerin görüşleri baz alınarak hazırlanan açık uçlu sorulara yer yerilmiştir. Bu sorular da içerik analizine tabi tutularak değerlendirilmiştir.

Araştırmanın evrenini; İstanbul'da sağlık yönetimi bölümü öğrencilerinin staja çıktıkları kurumlarda (6 kamu hastanesi, 5 özel hastane), çalışmış oldukları birimlerin yöneticileri oluşturmaktadır. Araştırmada evrenin tamamına ulaşılmaya çalışılmış ve çalışmaya katılmayı kabul eden kurumların birim yöneticilerine anket formu uygulanmıştır.

Araştırma verileri SPSS 20 paket programıla değerlendirilmiştir. Çalışmanın analiz aşamasında sıklık, aritmetik ortalama, standart sapma ve faktör analizi analizleri kullanılmıştır. Araştırmada kurumlardan izin alma aşamasında etik kurul kararına gerek duyulmadığı ve sosyal bilimler kapsamında tanımlayıcı bir araştırma yürütüldüğünden dolayı etik kurul iznine başvurulmamıştır.

\section{Bulgular}

Araştırmaya katılmayı kabul eden birim yöneticilerinin demografik özellikleri Tablo 1'de belirtilmektedir. Araştırmaya katılan yöneticilerin \%23,5', 22-31 yaş aralığında, \%22'si 32-40 yaş aralığında ve kalan \%33,3'ü 41 yaş ve üzerindedir. Araştırmaya destek veren katılımcıların \%51'i kadınlardan oluşmaktadır. Çalışılan birimler değerlendirildiğinde katılımcıların büyük bir çoğunluğunun $(\% 54,9 ; n=28)$ idari hizmetlerde görev yaptığı anlaşılmaktadır. Araştırma 
sonuçlarına göre yöneticilerin büyük kısmı lisans ve lisansüstü eğitim almıştır $(\% 77,5)$. Birim yöneticilerinin mesleki deneyimleri değerlendirildiğinde 6-10 yıl arası deneyim sahibi olanların birim yöneticilerinin \%35,3'ünü oluşturduğu sonucuna ulaşılmıştır. Araştırmaya katılan birim yöneticilerinin \%62,7 kamu kurumunda, \%37,3’ü özel kurumlarda yer almaktadir.

Tablo 1: Demografik Özellikler

\begin{tabular}{|c|c|c|c|}
\hline & & $\mathrm{n}$ & $\%$ \\
\hline \multirow{4}{*}{ Yaş } & 22-31 Yaş & 12 & 23,5 \\
\hline & 32-40 Yaş & 22 & 43,1 \\
\hline & 41 ve üzeri yaş & 17 & 33,3 \\
\hline & Toplam & 51 & 100 \\
\hline \multirow{3}{*}{ Cinsiyet } & Kadın & 26 & 51 \\
\hline & Erkek & 25 & 49 \\
\hline & Toplam & 51 & 100 \\
\hline \multirow{8}{*}{ Birim } & İdari hizmetler & 28 & 54,9 \\
\hline & Mali işler & 15 & 29,4 \\
\hline & Otelcilik & & \\
\hline & Hizmetleri & 3 & 5,9 \\
\hline & Tibbi Hizmetler & 4 & 7,8 \\
\hline & Toplam & 50 & 98 \\
\hline & Cevapsız & 1 & 2 \\
\hline & Toplam & 51 & 100 \\
\hline \multirow{6}{*}{$\begin{array}{l}\text { Öğrenim } \\
\text { Durumu }\end{array}$} & Lise & 3 & 5,9 \\
\hline & Önlisans & 7 & 13,7 \\
\hline & Lisans & 26 & 51 \\
\hline & Lisansüstü & 14 & 27,5 \\
\hline & Diğger & 1 & 2 \\
\hline & Toplam & 51 & 100 \\
\hline \multirow{6}{*}{$\begin{array}{l}\text { Mesleki } \\
\text { Deneyim }\end{array}$} & $1-5$ y1l & 9 & 17,6 \\
\hline & $6-10$ y1l & 18 & 35,3 \\
\hline & $11-15$ y1l & 8 & 15,7 \\
\hline & $16-20$ y1l & 7 & 13,7 \\
\hline & 21 yıl ve üzeri & 9 & 17,6 \\
\hline & Toplam & 51 & 100 \\
\hline \multirow{3}{*}{$\begin{array}{l}\text { Kurumun } \\
\text { Mülkiyeti }\end{array}$} & Kamu & 32 & 62,7 \\
\hline & Özel & 19 & 37,3 \\
\hline & Toplam & 51 & 100 \\
\hline
\end{tabular}

Araştırma formu, daha önceki çalışmalarda açımlayıcı faktör analizine tabi tutulmamış ve alt boyutları ortaya konulmamıştır. $\mathrm{Bu}$ sebeple; öğrenciler hakkında yöneticilerin verdiği cevaplar değerlendirilirken daha güçlü analizler yapılabilmesi amacıyla faktör analizi uygulamasına gidilmiştir. Verilerin öncelikle faktör analizine uygun olup olmadığını test edilmiştir. Bu bağlamda KMO ve Barlettt Testi sonuçları Tablo 2'de gösterilmektedir. KMO değerinin 0,80 ve 0,90 arasında olmas1 veri setinin faktör analizine iyi derecede uygun olduğunu göstermektedir. Bizim çalışmamızda bu değer 0,88 olarak tespit edilmiştir. Bartlett testi sonuçlarına göre $\alpha=0,000$ olduğu sonucuna ulaşılmış ve gerek veri setinin, gerek örneklem büyüklüğünün faktör analizine uygun olduğu tespit edilmiştir. Açıklanan toplam varyans ise; $\% 74,81$ olarak bulunmuştur.

Tablo 2: KMO ve Barlett's Testi Sonuçları

\begin{tabular}{lll}
\hline $\begin{array}{l}\text { Kaiser-Mayer-Olkin (KMO) Örneklem } \\
\text { Ölçüm Değer Yeterliliği }\end{array}$ & 0,885 \\
\hline Barlett Testi & Ki-Kare & 1311,27 \\
& df & 351 \\
& Sig. & 0,000 \\
\hline
\end{tabular}

Yapılan faktör analizi sonucunda ölçeğin dört boyuttan oluştuğu tespit edilmiştir (Tablo 3). $\mathrm{Bu}$ boyutlar literatürden yararlanarak; işbirliği ve uyum, sorumluluk, yeterlilik ve kişisel gelişim olarak isimlendirilmiştir. İşbirliği ve uyum boyutu 12 ifadeden oluşmakta ve güvenilirlik katsayısı 0,99'dur. Sorumluluk boyutunda 6 ifade yer almaktadır ve güvenilirlik katsayısı 0,93'tür. Yeterlilik katsayısı 6 ifadeden oluşmaktadır ve 0,89 güvenilirlik katsayısına sahiptir. Son olarak kişisel gelişim alt boyutu 3 ifadelidir ve güvenilirlik katsayısı 0,74 olarak bulunmuştur.

Anket değerlendirme skalasına göre ögrencilerin aldıkları puanlar incelendiğinde bütün boyutlarda staj yapan sağlık yönetimi öğrencilerinin iyi düzeyde puan aldıkları anlaş1lmaktadır (Tablo 4). Öğrenciler; iş birliği ve uyum alt boyutundan 2,13 $\pm 0,69$; sorumluluk alt boyutundan 2,36 $\pm 0,83$; yeterlilik alt boyutundan $2,44 \pm 0,80$ ve kişisel gelişim alt boyutundan 2,42 $\pm 0,76$ puan almışlardır.

İşletmenizin Stajyer seçiminde dikkat ettiği en önemli 5 kriter nedir şeklinde sorulan soruya verilen cevaplardan \%20,48'i eğitim seviyesi; \%14.45'i tutum ve davranışlar olmuştur. Çalışmada dikkat çeken diğer kriterler ise; diksiyon $(\% 13,25)$, uyumluluk $(\% 9,63)$ ve anlama becerisi $(\% 7,22)$ olmuştur. Belirtilen bu 5 kriter tüm cevapların arasında \%65,03'lük bir dilimi oluşturmaktadır. Gelen diğer cevaplar arasında ise; kılık-kıyafet, başarı, sorumluluk, disiplin, özen ve dürüstlük gibi kavramlar yer almıştır (Tablo 5). 
Sorduğumuz bir diğer açık uçlu soruda "staj döneminde öğrencilerle yaşanan sorunlar"ın neler olduğunu araştırdık. Bu soruya verilen cevaplar ve gelen cevaplar arasındaki yüzdelik

Tablo 3: Faktör Analizi Sonuçları

\begin{tabular}{|c|c|c|c|c|}
\hline Faktörün Ad1 & Soru İfadesi & $\begin{array}{c}\text { Faktör } \\
\text { yükü }\end{array}$ & $\begin{array}{c}\text { Faktörün } \\
\text { Açılklayıc1lığ } \\
(\%)\end{array}$ & $\begin{array}{c}\text { Cronbach } \\
\text { Alfa }\end{array}$ \\
\hline \multirow{12}{*}{$\begin{array}{l}\text { İşbirliği ve } \\
\text { Uyum }\end{array}$} & $\begin{array}{l}\text { Stajyerlerin araç ve gereçleri usulüne uygun kullanma } \\
\text { yeteneği }\end{array}$ & 0,809 & \multirow{12}{*}{25,993} & \multirow{12}{*}{0,995} \\
\hline & Stajyerlerin iş disiplinine ve iş ahlakına özeni & 0,778 & & \\
\hline & Stajyerlerin konuşma ve davranışlarında özeni & 0,725 & & \\
\hline & $\begin{array}{l}\text { Stajyerlerin malzemeleri israf etmeden kullanma } \\
\text { yeteneği }\end{array}$ & 0,666 & & \\
\hline & Stajyerlerin kılık-kıyafet ve disiplin uyumu & 0,651 & & \\
\hline & Stajyerlerin beklenen işi anlama becerisi & 0,634 & & \\
\hline & $\begin{array}{l}\text { Stajyerlerin mesai arkadaşlarına karşı tutum ve } \\
\text { davranışları }\end{array}$ & 0,610 & & \\
\hline & Stajyerlerin mesai arkadaşları ile uyumu & 0,606 & & \\
\hline & Stajyerlerin genel değerlendirilmesi & 0,603 & & \\
\hline & Stajyerlerin işyerine karşı tutum ve davranışları & 0,579 & & \\
\hline & Stajyerlerin yeni metotları öğrenme kapasitesi & 0,555 & & \\
\hline & Stajyerlerin yeni metot ve yöntemlere uyumu & 0,514 & & \\
\hline \multirow{6}{*}{ Sorumluluk } & Stajyerlerin işine karşı tutum ve davranışları & 0,752 & \multirow{6}{*}{21,619} & \multirow{6}{*}{0,935} \\
\hline & Stajyerlerin işine karşı sorumluluk duygusu & 0,726 & & \\
\hline & Stajyerlerin işe devam konusunda gösterdiği özen & 0,720 & & \\
\hline & Stajyerlerin talimatlar konusunda gösterdiği özen & 0,661 & & \\
\hline & Stajyerlerin mesai saatlerine karşı özeni & 0,623 & & \\
\hline & Stajyerlerin sorumluluk alma kapasitesi & 0,611 & & \\
\hline \multirow{6}{*}{ Yeterlilik } & $\begin{array}{l}\text { Stajyerlerin işle ilgili tüm detaylar verilmeksizin } \\
\text { yapabilme yeteneği }\end{array}$ & 0,861 & \multirow{6}{*}{16,313} & \multirow{6}{*}{0,899} \\
\hline & $\begin{array}{l}\text { Stajyerlerin okulda almış oldukları uygulamalı eğitimin } \\
\text { yeterliliği }\end{array}$ & 0,719 & & \\
\hline & Stajyerlerin işini denetlenmeden yapabilme yeteneği & 0,591 & & \\
\hline & $\begin{array}{l}\text { Stajyerlerin işiyle ile ilgili, sorunların çözümünde } \\
\text { göstermiş olduğu özen }\end{array}$ & 0,572 & & \\
\hline & $\begin{array}{l}\text { Stajyerlerin okulda almış olduğu teorik eğitimin } \\
\text { yeterliliği }\end{array}$ & 0,563 & & \\
\hline & Misafirlerinizin stajyerlerden memnuniyet durumu & 0,553 & & \\
\hline \multirow{3}{*}{$\begin{array}{l}\text { Kişisel } \\
\text { Gelişim }\end{array}$} & Stajyerlerin yabancı dil bilgisinin yeterliliği & 0,816 & \multirow{3}{*}{10,950} & \multirow{3}{*}{0,74} \\
\hline & Stajyerlerin öğrendikleri uygulama yeteneği & 0,675 & & \\
\hline & Stajyerlerin işi ile ilgili kendini geliştirme kabiliyeti & 0,518 & & \\
\hline
\end{tabular}

Tablo 4. Öğrencilerin Puan Ortalamaları

\begin{tabular}{lcc}
\hline & Ortalama & $\begin{array}{l}\text { Standart } \\
\text { Sapma }\end{array}$ \\
\hline İş birliği ve Uyum & 2,13 & 0,69 \\
Sorumluluk & 2,36 & 0,83 \\
Yeterlilik & 2,44 & 0,80 \\
Kişisel Gelişim & 2,42 & 0,76 \\
\hline
\end{tabular}

dağılımı Tablo 6'da gösterilmektedir. Gelen cevapların \%28,98'inde “öğrencilerin mesai kavramına uyumunda sorunlar" olduğunu göstermektedir. "İşine özen göstermemeleri" gelen cevapların \%11,11'ini oluştururken; "öğrencilerin bilgi yetersizliği olduğu" cevapların \%9,87'sinde belirtilmiştir. Karşılaşılan diğer önemli sorunlar arasında "işe uyumsuzluk" \%8,64 iken; "sayg1 göstermeme" \%7,4 olarak tespit edilmiştir. Birim yöneticileri ayrıca "disiplin, devamsızlık, cep telefonuyla meşgul olma, kılıkkıyafet, sigara kullanımı” gibi sorunlar olduğunu da ifade etmişlerdir. 
Tablo 5. Stajyer Seçimi Kriterleri

\begin{tabular}{lc}
\hline $\begin{array}{l}\text { Stajyer seçiminde dikkat } \\
\text { edilmesi gereken kriterler }\end{array}$ & $\%$ \\
\hline Eğitim Seviyesi & 20,48 \\
Tutum ve Davranışlar & 14,45 \\
Diksiyon & 13,25 \\
Uyumluluk & 09,63 \\
Anlama Becerisi & 07,22 \\
Toplam & 65,03 \\
\hline
\end{tabular}

\section{Tartışma}

Son y1llarda sağlik, kaybedildiğinde değeri anlaşılan bir kavram olmaktan çıkmış ve koruyucu sağlık hizmetlerinin daha da popüler hale geldiği bir fenomen olarak dönüşüm sürecine girmiştir. $\mathrm{Bu}$ dönüşüm sürecinde hiç şüphesiz ki en büyük sorumluluk paydaşlardan sağlik profesyonellerine bırakılmaktadır. Sağlık sisteminin olmazsa olmaz insan kaynağı olan sağlık profesyonellerini yetiştirmek ülkemizde bilimsel temeller üzerine oturtulmuş olup, ülkemizin kıymetli birçok üniversitesinde gerek lisans düzeyinde gerekse lisansüstü düzeyde çağın gereklerine ayak uyduracak şekilde yürütülmektedir.

Tablo 6: Öğrencilerle Stajda Yaşanan Sorunlar

\begin{tabular}{lc}
\hline Staj Döneminde Yaşanan Sorunlar & $\%$ \\
\hline Mesai saatlerine uyumsuzluk & 20,98 \\
İşe özen göstermeme & 11,11 \\
Bilgi yetersizliği & 09,87 \\
İşe uyumsuzluk & 08,64 \\
Saygi göstermeme & 07,40 \\
Toplam & 58,00 \\
\hline
\end{tabular}

Drucker 1980'de “Gelecek on ya da yirmi yıl, yönetim kadrosunun neyi temsil edeceğine ve yönetimin verdiği sözlerin ne kadarını elle tutulur sonuçlara çevireceğine karar verecek 'krizlere' pek çok yönden ev sahipliği yapacak ve yönetim olgusu üzerinde odaklanan ilgi, önümüzdeki yıllarda üst kademe yönetiminin yapısına, bileşimine, niteliğine ve bu kademedeki insanlara kayacaktır. Yarın 'üst kademe' yönetimi, özellikle büyük örgütlerde geçmişte barındırdığından çok fazla sayıda insan barındıracaktır" diyerek yönetimde nitelikli eleman ihtiyacının sürekli bir artış eğilimde olduğunu ifade etmiştir. Sağlığın karmaşık ve emek-yoğun doğasından dolayı yönetsel alanda gerekli ilgiyi görmesi mutlak bir gerçektir. ${ }^{18}$

Yönetim eğitiminde yeni yaklaşımlara genel olarak bakıldığında modern yönetim eğitiminin hem lisans hem de lisansüstü eğitim seviyelerinde rutin ders programlarının takip edilmesi ve uygulanan programlarin sonucunda öğrencilerin teorik bilgi düzeylerinin ölçülmesinden çok daha fazlasını gerektirdiği görülmektedir. Buna göre yeni yönetim eğitimi yaklaşımları iyi bir yönetici adayının teoriden çok uygulama yolu ile tecrübe sahibi olan, iletişim yetenekleri yüksek, saha deneyimi fazla olan bir kişi olmasını gerektirmektedir. $\mathrm{Bu}$ yeni yaklaşımlar yakın gelecekte yönetim eğitiminde köklü değişiklikler yaşanmasına neden olacaktır. Yönetim eğitimindeki bu yeni yaklaşımlar sağlık kuruluşları yönetimi açısından düşünüldügünde sağlık kuruluşları için profesyonel yönetim kavramının yeni olmadığ 1 bilinmekle birlikte son yıllarda kaynak kıtlığı, yeni teknolojiler ve sağlıkta insan kaynakları sayısının nicelik olarak yetersizliği ile birlikte bunun gerekliliğinin daha çok arttığı bilinmektedir.

Geçmişten bu güne yapılan araştırmalarda, sağlık alanında hekimlerin yönetimde ağırlıklı olarak söz sahibi oldukları ve yönetim eğitimindeki yeni yaklaşımları bilmek ve uygulamak, uygulama ve deneyim sonucunda edinilen yönetim yeteneklerini geliştirmenin farkında olmaları gerektiği sonucuna ulaşılmıştır. Sağlık yönetimi alanında profesyonel yönetici becerileriyle donanmış insan kaynağ 1 yetiştirmeyi amaçlayan sağlık yönetimi lisans ve lisansüstü programları bilim ve sanatın ahengine katkıda bulunmaktadır. ${ }^{19}$

Staj uygulaması sonuç itibariyle öğrencilerin teorik bilgilerini pekiştirmelerinde ve uygulamaya dönüştürmelerinde oldukça önemli bir yere sahiptir. $\mathrm{Bu}$ uygulamalar aynı zamanda öğrencilerin kişisel ve mesleki eğitimlerine de katkı sağlamaktadır. Amerika'da 400 stajyer öğrenciyle yapılan bir araştırmadan çıkan sonuçlara göre staj eğitiminin öğrencilerin mesleki ve kişisel gelişimlerini arttırdığ 1 sonucuna ulaşılmıştır. ${ }^{20}$

Staj deneyimlerinin en önemli yararlarından birisi de öğrencileri alana hazırlamak olarak ifade edilmektedir. ${ }^{17}$ Öğrencelerin eğitim gördükleri alanda öğrencilikleri devam ederken, profesyonellerin 
gözetiminde kişisel gelişimlerinin artması staj uygulamasını oldukça önemli kılmaktadır. ${ }^{21}$

\section{Sonuç}

Sağl1k yönetimi lisans öğrencilerinin staj yaptıkları birimlerdeki yöneticiler tarafından değerlendirilmesi sonucunda öğrenciler; iş birliği ve uyum alt boyutundan $2,13 \pm 0,69$; sorumluluk alt boyutundan 2,36 $\pm 0,83$; yeterlilik alt boyutundan $2,44 \pm 0,80$ ve kişisel gelişim alt boyutundan $2,42 \pm 0,76$ puan almışlardır. Alınan bu puanlar, öğrencilerin alanda işbirliği ve uyum konusunda, sorumluluk alabilme konusunda, yeterlilik konusunda ve kişisel gelişim konusunda iyi düzeyde olduklarını göstermektedir.

Sağlık işletmelerinin stajyer seçiminde dikkat ettiği en önemli kriterler \%20,48'i eğitim seviyesi; \%14.45'i tutum ve davranışlar olmuştur. Diğer kriterler ise; diksiyon $(\% 13,25)$, uyumluluk $(\% 9,63)$ ve anlama becerisi $(\% 7,22)$ olarak tespit edilmiștir. Verilen cevaplar dikkate alındığında öğrencilerden eğitimlerinin yanında; tutum ve davranışlarını, diksiyonlarını, uyumluluklarını ve verilen işleri anlama becerilerini yüksek düzeye getirmeleri gerektiği sonucuna ulaşılmıştır.

Staj uygulaması sırasinca yöneticilerin öğrencilerle yaşadığı sorunlar arasında mesai kavramına uyumun, İşine özen göstermeme, bilgi yetersizliği, işe uyumsuzluk ve saygı göstermeme olarak tespit edilmiştir. Birim yöneticileri ayrıca disiplin, devamsızlık, cep telefonuyla meşgul olma, kılık-kıyafet, sigara kullanımı gibi sorunlar olduğunu da ifade etmişlerdir.

Çalışmanın yöneticiler gözünden öğrencileri değerlendiriyor olması, araştırmayı özgün kılmış olup, sonraki çalışmalarda staj uygulamasında karşılaşılan sorunlar derinlemesine tespit edilerek, uygulamayı daha verimli hale getirecek adımlar atılabilir.

\section{Yazarların Katkılar}

Yazarlar, araştırmanın planlanmasına, uygulanmasına ve yayına hazırlanmasına eşit düzeyde katkı sağlamıştır.

\section{Kaynaklar}

1. Constitution of the World Health Organization 1946 [updated 1948; cited 2016 October 18]. Available from http://www.who.int/about/definition/en/print. $\underline{\mathrm{html}}$

2. Can A, İbicioğlu H. Yönetim ve yöneticilik yönünden üniversite hastanelerinin değerlendirilmesi. Süleyman Demirel Üniversitesi İktisadi ve İdari Bilimler Fakültesi Dergisi 2008; 13(3):253-75.

3. Deaton A. The great escape: health, wealth, and the origins of inequality. New Jersey:Princeton University Press; 2015. p.150.

4. Gupta P, Burns DJ, Schiferl JS. An exploration of student satisfaction with internship experiences in marketing. Business Education \& Administration, 2010;2(1):2737.

5. Çetin Ş. Öğrenci stajlarında yararlanılan dersler üzerine ampirik bir değerlendirme. Anatolia: Turizm Araştırmalart Dergisi 2005;16(12):153-69.

6. Bellini LM, Baime M, Shea JA. Variation of mood and empathy during internship. Jama 2002; 287(23):3143-3146.

7. Demir K. Stajyerlik kavramının insan kaynakları yönetiminin eğitim ve geliştirme işleviyle ilgisi ve bir araştırma [Yüksek Lisans Tezi]. Marmara Üniversitesi, İstanbul, 2010.

8. Maskooki K, Rama D, Raghunandan K. Internships in undergraduate finance programs. Financial Practice and Education 1998; 8:74-82.

9. Coco M. Internships: A try before you buy arrangement. SAM Advanced Management Journal 2000;65(2):41-7.

10. T.C. İstanbul Üniversitesi İstanbul Üniversitesi Sağlık Bilimleri Fakültesi Sağlık Yönetimi Bölümü Staj Yönergesi. 2014 [cited October 2016]. Available from http://sabif.istanbul.edu.tr/saglikyonetimi/wpcontent/uploads/2014/07/STAJYONERGESI.pdf

11. Demir M, Demir ŞŞ. Turizm işletmelerinde yöneticilerin mesleki staj ve stajyerleri değerlendirmesi. Marmara Sosyal Araştırmalar Dergisi 2014;(6):18-33. 
12. Özer M, Bakır B. Sağlık personelinin motivasyonuyla ilgili etmenlerin belirlenmesi. Gülhane Tip Dergisi 2003;42(2):117-22.

13. Şener E, Erdem R, Akçakanat T. Türkiye’de lisans düzeyinde sağlı yöneticisi yetiştiren kurumların akademik ve eğitsel profili. Hacettepe Să̆lı İdaresi Dergisi 2010;13(1):29-44.

14. ÖSYS Yükseköğretim Kontejyanları Klavuzu. 2016 [cited October 2016]. Available from http://dokuman.osym.gov.tr/pdfdokuman/201 6/LYS/TERCIH/OSYSKONTKILAVUZU29 072016.pdf

15. Jamison K, Clayton J. Exploring the experiences of administrative interns: implications for university preparation programs. Journal of Educational Administration 2016;54(5):514-536.

16. Bos D, Finlay R, Hopkins P, Lloyd J, Richardson M. Reflections on the ESRC internship scheme for postgraduates. Journal of Geography in Higher Education 2017;41(1):106-118.

17. Dayığlu M. Anadolu otelcilik ve turizm meslek lisesi stajyer öğrencilerinin yeterliliği konusunda işveren görüşleri (Edremit körfezi örneği) [Yüksek lisans tezi]. Balıkesir Üniversitesi, Balıkesir, 2010.

18. Çınaroğlu S. Yönetim eğitiminde yeni yaklaşımlar ve hastanelerde profesyonel yönetici ihtiyacı. Hacettepe Sağllk İdaresi Dergisi 2010; 15(1):70-110.

19. 16-Marlborough K. Development and validation of an Instrument to assess student satisfaction with community college Internships [PHD Thesis]. University of Lowa, USA,1999.

20. Knouse SB, Gwen F. Benefits of the business college internship: a research review. Journal of Employment Counseling 2008;45(2):61-66.

21. Halfer D. A magnetic strategy for new graduate nurses. Nursing Economics 2007;25(1):6-11. 